\title{
Organization and Management of Female Sports Development in Albania
}

\author{
Koci Ledina \\ Sport University of Tirana, Faculty of Movement sciences Depatament of Sports \\ Email:Ledina.koci@yahoo.com

\section{Elmazi Rovena}

Sport University of Tirana,Faculty of Physical Activity and Recreation Departament of Organisation \& Menagement; Email:rd.elmazi@gmail.com

Plasa Migena

Institute of sport Research, Sports University of Tirana

\section{Doi:10.5901/ajis.2016.v5n3p159}

\section{Abstract}

\begin{abstract}
Throughout the transition period Albania faced great challenges to create its future and such transition was very long and difficult. It was a long process of amendments including a comprehensive structural, economic, legal, cultural, and social and sports related package. The designing of reforms and institutions was oriented towards political aims and the quickest reforming occurred in less expensive areas. Such orientation resulted as well in consequences to the development of sports in Albania and female teams in particular. The poor organization of several bodies responsible for the development of sports in our country has led to serious consequences on the progress of female sports. The sports clubs in cooperation with the respective federations must draft special inspection programme to identify talents, promote sports values and cooperation with the teachers of physical education and parents so as to raise awareness and encourage as many girls as possible to become part of sports teams and above all orient them towards the proper discipline. Orientation towards the proper discipline is fundamental and it may be done only by the sports specialists who must see the physical, motor, psychic, anthropometric etc development in order to further assess the discipline to which they may be better aligned with. This is an important task to be performed quickly in order to re-establish female sports in Albania, because currently it is not representation by national teams in international events, due to the fact that girls, at an early age, prefer to be involved in ballet or dance so as to follow the traces of the good-looking ballet dancers and make reality their dream of becoming just like them.
\end{abstract}

Keywords: organization and management, non-constructive policies, sports discipline, discovery of talents

\section{Introduction}

In the process of sports development, management aspects are of fundamental importance. Management for the purpose of this paper shall mean leadership, guidance, organization in the process of sports development. Theoretical treatment, Drafting Of Effective Strategic Projects And Strict Application Are The Fundamental Provisions To Achieve Successful Progress Of Female Sports.

There Exists Abundant Literature On Organization Structure From 1950 Onwards. There Is Mintzberg's Work On Topologies Based On Different Structural Design (Mintzberg's , 1979).Burns And Stalker's Type Of Organizational Structure According To Different Environmental Conditions (Burns And Staker's,1961) ,Child's Structuring Of Activities Inside The Organisation(Child's,1972) And Miller's And Snow's Conception Of Structure Based On The Strategy Of The Organisation(Miles And Snow,1978),Among Many Others. The Interest In Studying Organizational Structure Resides In The Relationship Between Organizational Design And Other Organizational Phenomena ,Like Is Performance ,Distribution Of Power ,Or Control Systems .While There Is Plenty Of Literature On Organizational Structure Studying Different Types Of Organizations .Little Is Written In Book And Journal On The Specific Field Of Sport Organisations .Although Research On The Particular Nature Of Sports Organisation And Their Characteristics Is Still Scarce, The Article "Sport And Organizational Studies :Exploring Synergies"(Wolfe Et Al., 2005) Present E Literature Review In Which They Cover A Broad Spectrum Of Research Studying Organizational Phenomena In The Context Of Sports. The School 
And Family Constitute The Main Link Of The Chain And Two Important Factors In Education And Guidance Of Children Putting Special Emphasis On The Importance And Significance Of Doing Sports And Their Choice Of Various Disciplines Suitable To Their Motor Development. Such Cooperation Must Be Extended Further To The Representatives Of Sports Associations Responsible For The Establishment And Development Of Teams Of All Ages Of Female Players So: The Main Question Of This Study Is What Is The Importance Of Cooperation Between Parents ,Schools Teachers, Team Trainer And Respective Federation To Increase The Number Of Females In The Basketball Teams Of Various Group Ages?This Is An Important And Fundamental Link Of The Chain To Set In Motion All The Mechanisms Which Must Be Based On The Real And Functional Objectives Including The Need The Cooperation, Training/Exercise Forms, Measure To Improve work conditions of trainers, measures for the success of teams.

\section{Aim and Object of the Study}

The aim of this study is to urge the further institutional cooperation in our country as an important instrument for the development of sport for females which in the recent years has been deteriorated because of the long transition.

The object of the study is: to evaluate practically the participation of females in basketball sports.

\section{Methodology}

The subject of this study will be the females aged U 12; U 14;U16;U18 And first team as well as the specialists who work with this ages because they are considered as groups who the study will be relied on and also the specialists and coaches are the ones who will take advantage of this study.We are based on our experience as physical education teacher and basketball trainers of various age-groups for several years. In order to show the importance of this chain, this study was made to present real data in cooperation with the Albanian Basketball Federation. The starting point is the presentation of involvement of females throughout the year and then the increasing progress as a result of application on site of this kind of management.

\section{4. $\quad$ Result}

The statistics obtained by the Albanian Basketball Federation clearly show that such institutional cooperation is quite useful not only in the development of basketball but also in the involvement of as many females in these teams.

The following data are drawn and presented in the following tables and graphs.

\begin{tabular}{|l|c|c|c|}
\hline TEAM FEMALES & $\mathbf{2 0 1 1 - 2 0 1 2}$ & $\mathbf{2 0 1 2 - 2 0 1 3}$ & $\mathbf{2 0 1 3 - 2 0 1 4}$ \\
\hline First team & 85 & 100 & 105 \\
\hline U18 female & 129 & 101 & 92 \\
\hline U16 female & 0 & 39 & 111 \\
\hline U14 female & 13 & 11 & 53 \\
\hline U12-U10 female & 0 & 0 & 10 \\
\hline
\end{tabular}

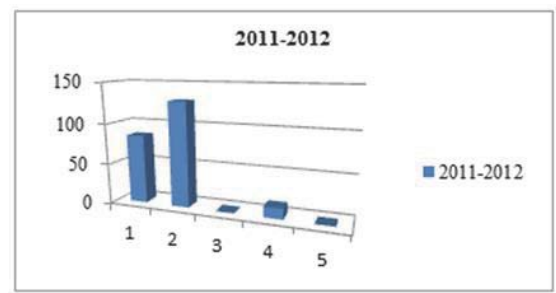

Figure 1. The number of females involved in three years period 


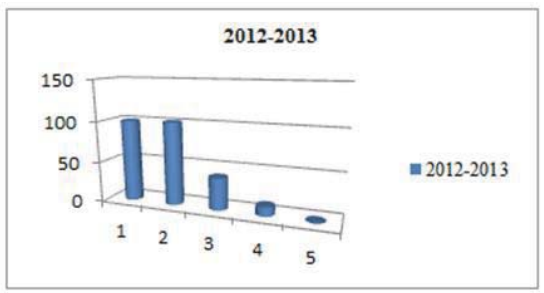

Figure 2. Females involved in 2011-2012

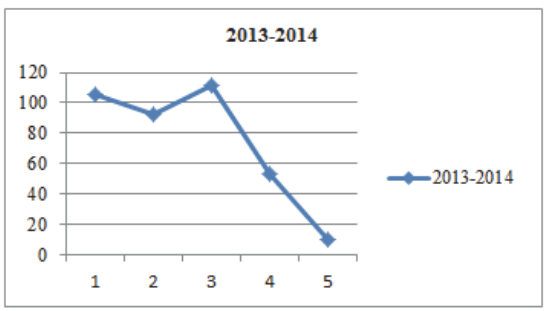

Figure 3. Females involved in 2012-213

Figure 4. Females involved in 2013-2014

\begin{tabular}{|c|c|}
\hline Total number of female basketball player in years \\
\hline $2011 / 2012$ & 228 \\
\hline $2012 / 2013$ & 253 \\
\hline $2013 / 2014$ & 389 \\
\hline TOTAL & 870 \\
\hline
\end{tabular}

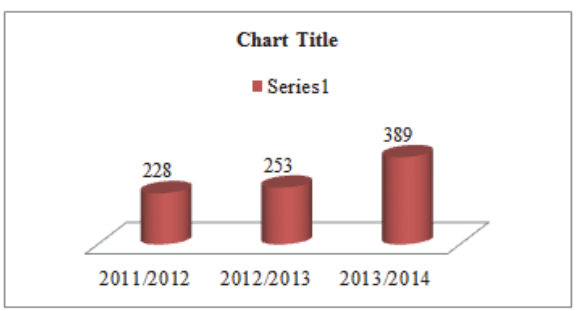

Figure 6.Total females involved in three years

Based in the result of data we found more females involved in basketball team so in the process of sports development, management aspects are of fundamental importance. Management for the purpose of this paper shall mean leadership, guidance, organization in the process of sports development. Theoretical treatment, drafting of effective strategic projects and strict application are the fundamental provisions to achieve successful progress of female sports.

\section{Discussion}

The public sports institution in Albania have been affected by the years of transition in Albania. Following the government changes and social and economic problems of the country, sports was seriously shocked and it is still going through a long phase of transition imposed by the social development conditions in general and expressed in the lack of proper development conditions, and, of course, lack of strategies for its future. The biggest absurdity in sports is that there is a 
deep contradiction between the institutions and consequences suffered by the sportsmen and teams depending on the respective disciplines. The country has suffered by the bad relations within the community throughout the years and such relations have somehow settled during the last years. Individual histories of Albanian sportsmen and lack of chain teams in various sports disciplines are the best testimony of underestimation of sports in the country. The comprehensive support given to sportsmen and those engaged in sports activities and also the support to the variety of sports activities is completely deficient.

In Albania there is no partnership between the government and sports institutions and the law on sports is not being implemented. The legislative gaps are reflected as a multiple burden on the sports system in the country because of lack of strategies by the central institutions and federations or clubs as well.

Improper management resulting from incapacity of central institutions and their clientele interests have led to the collapse of public, institutional and infrastructural sports development capacity in the country. One of the priority steps taken in this sector is immediately taking the sports legislation out of this chaotic situation, its adaptation to international standards and norms and definition of administrative measures which ensure its strict implementation.

One of the steps taken recently by the government is the creation of the "university sports federation" and "school sports federation" which will serve to coordinate and revive sports life in all the schools of the country by means of curricula and extra-curricula sports activities.

Moreover, the evaluation of basic motor skills of children from 3-6 years old will be included in the state standard curricula. Such initiative will encourage the new generation to undertake sports disciplines and increase the number of females which during the last years has been quite low.

Lack of inclusiveness results not only in impossibility to build chain teams, but to identifying talents in this field. Adding the number of physical education classes is a good opportunity for involvement of students in all the disciplines and a facility for the teachers of physical education to identify the skills of each student and guide them further to the teams of ages in the sports of their talent. This is the solution to having new entries to the teams and consequently quality of respective sports that is reflected in the work of respective sports association and federations and other institutions responsible for the organization and development of sports in our country.

\section{Conclusion}

The main role of management is leadership of activities, strict organisation of responsible structures to move towards the required objective. Consequently, organisation in cooperation with the school and parents to orient the girls towards basketball is essential in sports development. Their increasing participation is leading to the establishment of teams of all group-ages, development of championships of each age group and re-establishment of national teams of each agegroup. Such strategic project is resulting in the increase of the quality of the basketball among the female players.

\section{References}

Bates M. (2008)- Health Fitness Management- Human Kinetics

Burn's .T, and Stalker, G.M (1961),The management if innovation, "London, Tavistock

Child, J. (1972)"Organization structure and strategies of control; A replication of the Aston study, " Administive Science Quaterly, 18,pp 328-348.

Chelladurai P, Madella A (2006)- Human Resource Management in Sport and Recreation- Human Kinetics

Centro sportivo italiano editore. Organizzare lo sport per tutti 1996

C T Hammett. Movement activity for Early Childhood 1992

D. Ermir.Public Administation. 2005

Hurd A.R, Barcelona R J, Melburm J T (2008)- Leisure services management - Human Kinetics

J C Harris, R J Park Play games and sports in cultural contexts 1983

Miloch K.S, Lancella P.C. (2007)- Strategic Sport Commmunication- Human Kinetics

Miles, R., and Snow, C. C (1978), Organizational strategy, structure and process ,"New York, McGraw Hill

Mintzberg, H (1979) "The structuration of organizations, "Englewood Cliffs, Prentice Hall.

Mull R.F, Bayless K.G. (2007)- Recreational Sport Management - Human Kinetics

Parks JB, Quarterman J, Thibault L. (2007)- Contemporary Sport Management- Human Kinetics

'Sport and organizational studies; Exploring synergy, "Journal of Management Inquiry,14(2),pp. 182-210

Sutton W.A, McCarthy LM (2008) - Sport Promotion and Sales Management- Human Kinetics

Spengler J.O, Connaughton D.P., Pittman A.T (2006)- Risk Management in Sport and Recreation - Human Kinetics

Wolf, R Weick, K.E., Usher, J.M, Terborg, J.R., Poppo , L., Murrell, A.J., et al. (2005)

Whyman W (2008) - Outdoor Site and Facility Management- Human Kinetics 